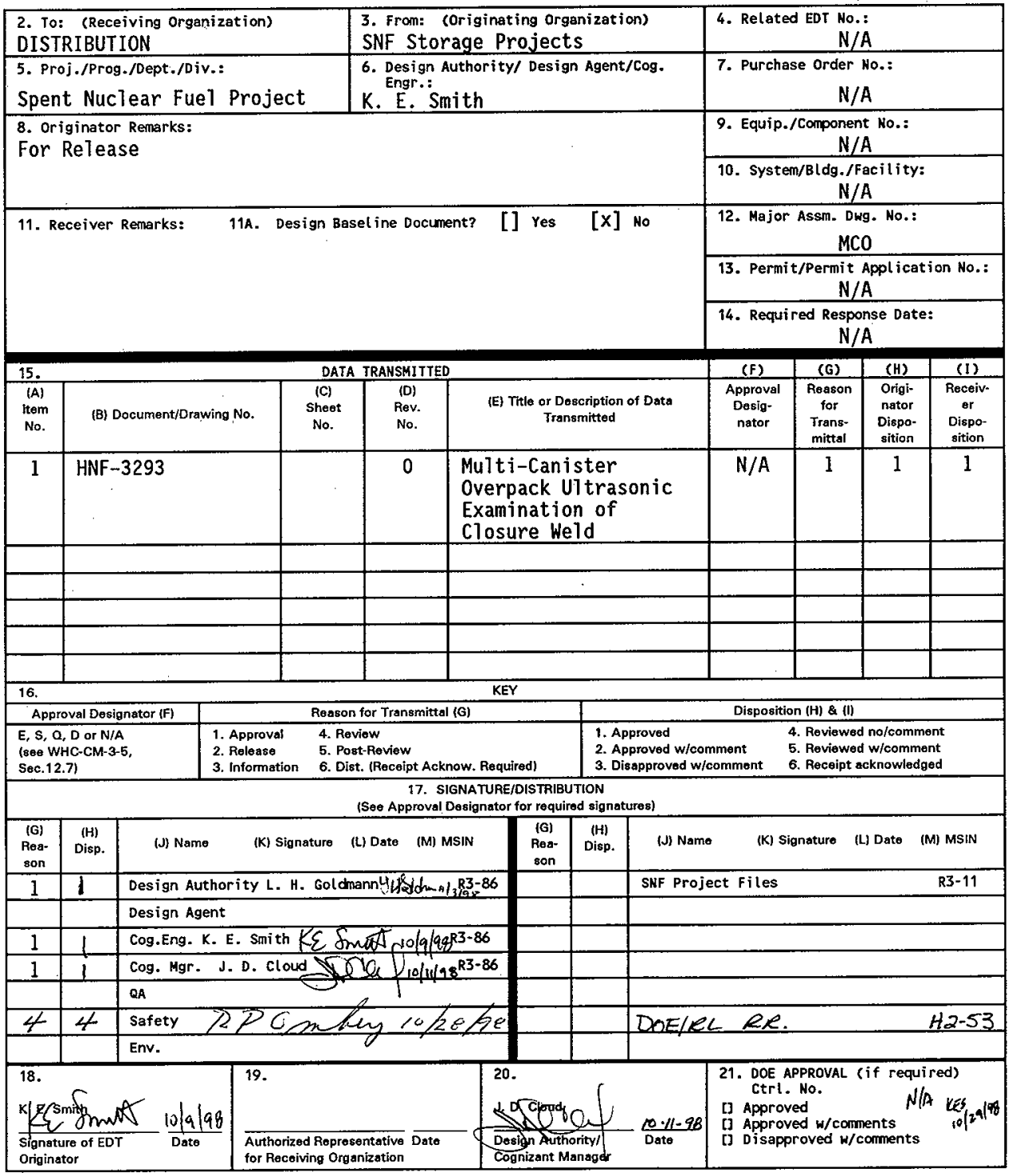




\title{
Multi-Canister Overpack Ultrasonic Examination of Closure Weld
}

\author{
K. E. Smith
}

DE\&S Hanford, Inc., Richland, WA 99352

U.S. Department of Energy Contract DE-AC06-96RL13200

$\begin{array}{lll}\text { EDT/ECN: } & 625779 & \text { UC: } 600 \\ \text { Org Code: } & 2 T 340 & \text { Charge Code: } 105532 / \text { AA30 } \\ \text { B\&R Code: } & \text { EW7040000 } & \text { Total Pages: } 5\end{array}$

Key Words: MCO, Spent Fuel, NDE, Packaging, Container, Issue, Ultrasonic, WeTd Examination

Abstract: The method used for non-destructive examination of the closure weld must provide adequate assurance that the weld is structurally sound for the pressure and lifting loads to be imposed, and must be consistent with NRC equivalency requirements established for the SNF Project. Given the large flaw size that would need to exist before the structural integrity of the weld is challenged, liquid penetrant testing of the root and final passes provides adequate assurance of weld quality to meet structural loads. In addition, the helium leak test provides confirmation that the containment boundary is intact and leaktight. While UT examination does provide additional evidence of weld integrity, the value of that additional evidence for this particular application does not justify performing UT examination, given the additional financial and ALARA costs associated with performing the examination.

TRADEMARK DISCLAIMER. Reference herein to any specific comercial product, process, or service by trade name, trademark, manufacturer, or otherwise, does not necessarily constitute or imply its endorsement, recomendation, or favoring by the United States Government or any agency thereof or its contractors or subcontractors.

Printed in the United States of America. To obtain copies of this document, contact: Document Control Services, P.0. Box 950, Mailstop H6-08, Richland WA 99352, Phone (509) 372-2420; Fax (509) 376-4989.
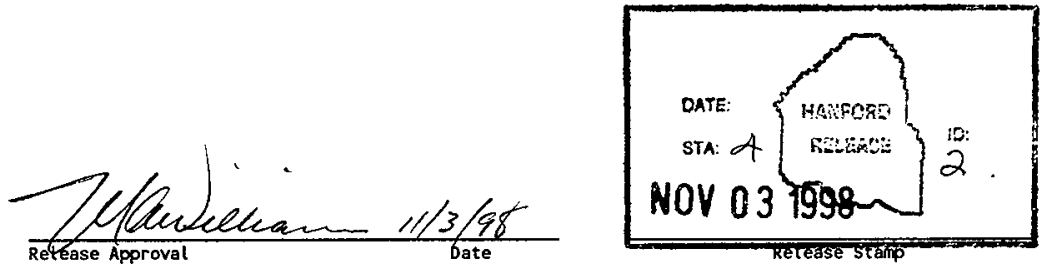

\section{Approved for Public Release}


HNF-3293, Rev.0

\section{Issue Closure Package}

Issue: MCO U1trasonic Examination of Closure Weld

Lead:

K. E. Smith
MCO Imp lementation
Manager, DE\&S Hanford

\section{Approvals:}

Chief Engineer: A. M. Segrest DE\&S Hanford

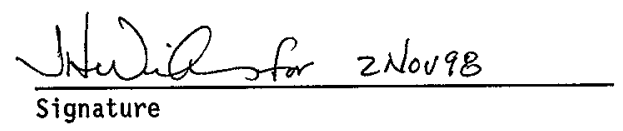

Technical Operations:

J. A. Swenson Manager DE\&S Hanford

Construction Projects:

A. R. Hollins Manager

DE\&S Hanford

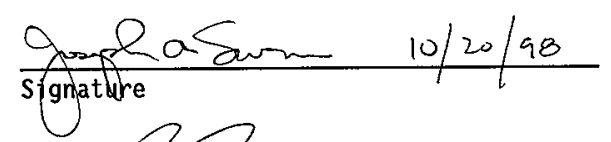

Nuclear Safety:

Robert G. Morgan Manager

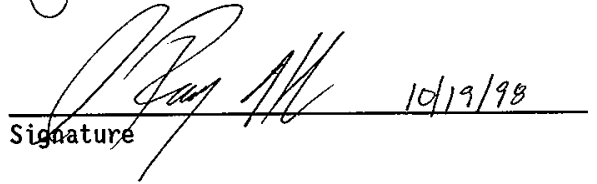

DE\&S Hanford

MCO Design Authority:

L. H. Goldmann

DE\&S Hanford

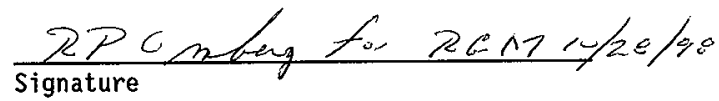
Gums iffitonom
$10 / 9 / 98$
Signature 
HNF-3293, Rev. 0

MULTI-CANISTER OVERPACK

ULTRASONIC EXAMINATION OF CLOSURE WELD

\section{Introduction}

The selection of appropriate non-destructive examination methods for the final closure weld is driven and influenced by ASME Code requirements and Code Cases, technical evaluations of the merits of examination methods, physical design contraints, and input from the Independent Review Panel (IRP) relative to NRC equivalency. While radiographic examination of the closure weld is not possible due to design imposed constraints, volumetric examination by use of uTtrasonics (UT) is feasible. The regulatory drivers for performing UT examination should be evaluated against the technical merits and cost of performing the examination.

\section{Discussion}

A key issue relevant to UT examination deals with the value and practicality of UT examination in this particular application. The material being joined, 304L stainless steel, is inherently tough, even after welding. Furthermore, considering the maturity of the welding process, there are no mechanisms in this particular situation that would degrade the toughness of the stainless steel materials, nor the weld joining them. To demonstrate this, a critical flaw analys is was performed by A7tran Corporation (Reference 1). This analysis, employing conservative assumptions, revealed that the critical flaw size is $1 / 8$ inch in depth, extending completely around the circumference of the MCO. Since it is estimated that about five to six weld passes will be required to make the final closure weld, each weld pass will be approximately $1 / 16$ inch thick. This dimension is smaller than the critical flaw depth. A flaw size large enough to compromise the integrity of the weld would be easily seen by an experienced welding operator. In addition, a liquid penetrant examination of the root pass and final pass would provide documented evidence of proper weld integrity. A helium leak test of the closure weld to demonstrate leaktightness to $1 \times 10-7 \mathrm{scc} / \mathrm{sec}$ is also $\mathrm{planned}$. While this leak test cannot be used to verify structural integrity, it does provide a confirmation of the containment boundary.

Previous interpretation of ASME Code requirements for the closure weld resulted in the position that UT examination was not permitted as a substitution for radiographic examination. However, after discussion with Mr. Roger Reedy, an ASME Code expert, it was learned that NB-5279 is applicable to the closure weld. Section III, NB-5279 allows UT as a substitute for radiographic examination - "ultrasonic examination plus liquid penetrant or 
HNF-3293, Rev. 0

magnetic particle examination of the completed weld may be substituted for the radiographic examination." Therefore, an exception to the Code would need to be documented if UT examination were not performed. However, the ASME Committee is currently reviewing a proposed Code Case for spent fuel storage canisters (Code Case N-595-1) which permits varying levels of liquid penetrant or magnetic particle examination for final closure welds in lieu of volumetric examination, with a weld stress reduction factor applied. For the MCO, application of the weld stress reduction factor will not impact the Service Level A pressure rating. ASME approval of this Code Case would preclude the need to document a Code exception in the design report or submit an $\mathrm{MCO}-$ specific Code Case.

Relying on liquid penetrant examination of closure welds in place of volumentric examination is consistent with previously NRC licensed spent fuel canister/casks. The issue of UT examination of the closure weld was discussed with the IRP during the July 8, 1998 SNF Project review meeting. The IRP position expressed at that meeting was that the NRC was not requiring UT examination for stainless steel closure welds, and that the SNF position justifying the omission of UT examination based on critical flaw analysis was reasonable and acceptable.

The cost of UT examination to provide additional evidence of weld integrity is substantial. The ROM cost for this activity is as follows:

- Purchase commercially available, manually set-up, remote-operated, automated UT systems (2 ea)

$\$ 175 \mathrm{~K}$ - \$300K each .$\$ 600 \mathrm{~K}$

- $\quad$ Spare remote automated UT system

(If required to ensure production welding schedule) $\ldots \ldots \ldots \ldots \$ 300 \mathrm{~K}$

- Additional tooling

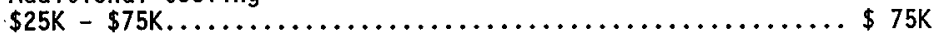

- Qualification of the test procedure

(No cost if provided by a commercial qualified firm)........ --

TOTAL UP-FRONT COSTS

$\$ 550 K-\$ 1000 K$

In addition to the up-front costs described above, there would be the actual costs of UT examination during production welding. For the purposes of this evaluation it is assumed that 200 MCOs will be welded each year for two consecutive years. Depending on the operational sequence, interferences caused by other operations at the weld station during operational welding, and actual throughput of the MCOs during operations, the cost of UT examination is estimated to be between $\$ 150 \mathrm{~K}-\$ 350 \mathrm{~K}$ per year for a total estimated cost for two years of between $\$ 300 \mathrm{~K}-\$ 700 \mathrm{~K}$. The total additional cost associated 
HNF-3293, Rev. 0

with performing UT examination of $400 \mathrm{MCOS}$ is estimated at approximately $\$ 1.0$ million to $\$ 2.0$ million. In addition to the added cost of performing UT examination, there are ALARA costs which would be increased due to the UT activities performed around the loaded MCO.

\section{CONCLUSION}

The method used for non-destructive examination of the closure weld must provide adequate assurance that the weld is structurally sound for the pressure and lifting loads to be imposed, and must be consistent with NRC equivalency requirements established for the SNF Project. Given the large flaw size that would need to exist before the structural integrity of the weld is challenged, liquid penetrant testing of the root and final passes provides adequate assurance of weld quality to meet structural loads. In addition, the helium leak test provides confirmation that the containment boundary is intact and leaktight. While UT examination does provide additional evidence of weld integrity, the value of that additional evidence for this particular application does not justify performing UT examination, given the additional financial and ALARA costs associated with performing the examination.

\section{REFERENCES}

1. Letter Report, R.E. Smith, Altran Corporation, to B.J. Kruse, Duke Engineering and Services, "Final Letter Report for CP98127 "Critical Flaw Size Analysis for Stainless Steel End Cap Weld in Multi-Canister Overpack", \#98127C.1, dated April 20, 1998 


\section{DISTRIBUTION COVERSHEET}

Subject: MCO ISSUE PAPERS PER ATTACHED DISTRIBUTION INDEX

\section{DISTRIBUTION}

\begin{tabular}{|c|c|c|}
\hline Name & Location & w/att \\
\hline \multicolumn{3}{|c|}{ Spent Nuclear Fuel Project } \\
\hline W. C. Alaconis & $\mathrm{R} 3-86$ & $X$ \\
\hline G. D. Bazinet & S8-06 & $X$ \\
\hline J. D. Cloud & $\mathrm{R} 3-86$ & $\mathrm{X}$ \\
\hline D. R. Duncan & R3-86 & $\mathrm{X}$ \\
\hline J. R. Frederickson & $\mathrm{R} 3-86$ & $X$ \\
\hline L. J. Garvin & R3-26 & $\mathrm{X}$ \\
\hline L. H. Goldmann & $\mathrm{R} 3-86$ & $\mathrm{X}$ \\
\hline A. R. Hollins, Jr. & $\mathrm{R} 3-86$ & $X$ \\
\hline C. R. Hoover & R3-86 & $X$ \\
\hline J. J. Irwin & $\mathrm{R} 3-86$ & $X$ \\
\hline B. D. Lorenz & $\mathrm{R} 3-26$ & $\mathrm{X}$ \\
\hline C. R. Miska & R3-86 & $\mathrm{X}$ \\
\hline R. G. Morgan & $\mathrm{R} 3-26$ & $X$ \\
\hline R. P. Omberg & $\mathrm{HO}-40$ & $\mathrm{X}$ \\
\hline A. M. Segrest & $\mathrm{R} 3-11$ & $X$ \\
\hline R. A. Sexton & R3-86 & $\mathrm{X}$ \\
\hline K. E. Smith & R3-86 & $\mathrm{X}$ \\
\hline J. A. Swenson & $\mathrm{R} 3-11$ & $X$ \\
\hline N. H. Williams & R3-11 & $X$ \\
\hline Project File & R3-11 & $x$ \\
\hline \multicolumn{3}{|c|}{ U.S. Department of Energy } \\
\hline C. B. Loftis & S7-41 & $\mathrm{x}$ \\
\hline P. G. Loscoe & S7-41 & $X$ \\
\hline E. D. Sellers & S7-41 & $\mathrm{X}$ \\
\hline J. B. Sullivan & S7-41 & $\mathrm{X}$ \\
\hline
\end{tabular}




\section{DISTRIBUTION INDEX}

The Multi-Canister Overpack Issue papers listed below are being distributed as a package to facilitate future reference and use by SNF Project personnel. The following issue papers are attached:

1. HNF-2876, Oxygen Gettering Issue Closure Package

2. HNF-3265, MCO Number of Shield Plug Ports

3. HNF-3399, MCO Necessity of the Rupture Disk

4. HNF-3267, MCO Dual Pressure Rating

5. HNF-3293, MCO Ultrasonic Examination of Closure Weld

6. HNF-3354, MCO Monitoring Issue Closure Package and HNF-3312, MCO Monitoring Activity Description

7. HNF-3292, MCO Sealing Configuration

8. HNF-3266, MCO Design Pressure Rating

9. HNF-3255, ASME Code Requirements for MCO Design and Fabrication

10. HNF-3398, MCO Inservice Inspection and Maintenance

11. HNF-3420, MCO Internal HEPA Filters

12. HNF-3036, Low Reactive Surface Area Issue Closure Package

13. HNF-3270, MCO Pressure Testing 